\title{
Vaccination of Infants with Living Attenuated Measles Vaccine (Edmonston Strain) with and without Gamma-globulin
}

\author{
P. F. BENSON,* M.B., B.S., M.R.C.P., D.C.H. ; N. R. BUTLER, † M.D., M.R.C.P., D.C.H. ; \\ A. P. GOFFE, $\ddagger$ M.B., B.S., DIP.BACT. ; G. J. KNIGHT, F.I.S. ; G. D. LAURENCE, $\ddagger$ B.SC. ; \\ C. L. MILLER, $\|$ B.M., в.CH. ; T. M. POLLOCK,§ M.B., B.CH.
}

Brit. med. F., 1964, 2, 851-853

The first trials of measles vaccines in the United Kingdom were reported in 1961 by Aldous et al., when three living attenuated vaccines derived from the Edmonston strain (Enders et al., 1960) were compared at the Fountain Hospital. In many cases vaccination reactions were too pronounced for the vaccines to be suitable for routine use. However, in view of the high complication rate of measles in young children (Miller, 1964), it was considered important to continue clinical trials of measles vaccine rendered less toxic by further attenuation. The present paper describes four subsequent trials of vaccines prepared from the Edmonston strain but which had undergone a further series of passages in chick-embryo or chick-cell tissue cultures. In some of the trials the vaccines were given alone, and in others concurrently with gamma-globulin.

\section{General Plan}

\section{Methods}

The trials were carried out in healthy infants or young children with no previous history of measles. Four separate studies were made: in each of the first three, two vaccines were compared, and in the fourth one vaccine was tested. When two vaccines were compared the children were allocated at random to receive one or other vaccine. A serum sample was taken immediately before vaccination and a second sample four weeks after vaccination. Virus-neutralizing antibody titres were determined on the pre- and post-vaccination samples in parallel (Goffe and Laurence, 1961). All children included in the analysis had no pre-vaccination antibody. Reactions to vaccination were assessed during the two weeks after vaccination.

\section{The Vaccines}

All the vaccines were freeze-dried suspensions of living attenuated measles virus derived from the Edmonston strain.

Vaccine 4A: This vaccine was essentially Enders's Edmonston $B$ vaccine. The preparation (Goffe and Laurence, 1961) and performance in a clinical study (Aldous et al., 1961) have been described previously.

Vaccine 14: This strain was derived from Enders's Edmonston A vaccine strain and had undergone three passages in chick-embryo tissue cultures at $37^{\circ} \mathrm{C}$., followed by 38 passages in chick-embryo tissue cultures at $33^{\circ} \mathrm{C}$. at seven-day intervals, and then by 24 passages at four- to five-day intervals in chick-embryo tissue cultures at $33^{\circ} \mathrm{C}$.

Vaccine 16: This strain was derived from vaccine 4A and had undergone 30 additional passages in seven- to eight-day-old chick embryos by the intra-amniotic route.

Vaccine 20: This strain was a descendant of Enders's Edmonston $B$ primary seed virus, and had been subjected to a total of 77 additional chick-embryo tissue-culture passages at $33^{\circ} \mathrm{C}$.

The preparation and testing of vaccines 14,16 , and 20 followed the procedure described previously (Goffe and Laurence, 1961), modified by the inclusion of supplementary tests in embryonated eggs and chick-embryo tissue cultures. The, final vaccines were given a more extensive safety test in animals than had been used previously. The virus content of each batch was titrated in tissue culture, using HEp-2 cells, by the $50 \%$ cytopathic endpoint method. It was later checked by retitration of samples of the final vaccines, which were returned unused from some of the immunization sessions. The virus titres per human dose of the vaccine were as follows: vaccine $4 \mathrm{a}, 10^{3.4}$ per ml.; vaccine $14,10^{3.2}$ per $\mathrm{ml}$; vaccine $16,10^{3.7}$ per $\mathrm{ml}$.; vaccine $20,10^{3.5}$ per $\mathrm{ml}$.

Study I. Comparison of Vaccine 4A and Vaccine 16 Using $0.02 \mathrm{ml}$. Gamma-globulin per lb. (0.044 ml./kg.) Body Weight With Each Vaccine

Vaccine 4A and vaccine 16 were given at Guy's Hospital Infant Welfare Clinic at Salomons' Centre. Gamma-globulin was given subcutaneously into another site at the time of measles vacrination. Fourteen infants aged 9 to 20 months received $4 \mathrm{~A}$, and 13 aged 9 to 16 months received vaccine 16 (Table I). A clinical examination and rectal temperature readings were made on each infant from the 6th to the 10 th day after vaccination. None of the 27 infants had a pyrexia greater than $102^{\circ} \mathrm{F}$. $\left(38.9^{\circ} \mathrm{C}\right.$.). All but three had temperatures of less than $101^{\circ}$ F. $\left(38.3^{\circ}\right.$ C.) (Table II). Morbilliform rashes were observed twice, but were transient and restricted in distribution. Many of the children had a nasal discharge during the followup, thought to be due partly to prevalent intercurrent infection. but any constitutional upset observed was slight and transitory. The serum of all but one of the children contained postvaccination measles antibody (Table III).

TABLE I.-Age of Participants in Each of the Four Studies (According

\begin{tabular}{|c|c|c|c|c|c|c|c|c|c|}
\hline \multirow{2}{*}{ Study } & \multirow{2}{*}{ Vaccine } & \multicolumn{7}{|c|}{ Age in Months } & \multirow{2}{*}{ Total } \\
\hline & & $5-8$ & $9-12$ & $13-16$ & $17-20$ & $|21-24|$ & $25-28$ & $>28$ & \\
\hline 1 (Guy's) \{ & $\begin{array}{l}4 \mathrm{~A} \\
16\end{array}$ & $\bar{z}$ & $\begin{array}{l}3 \\
4\end{array}$ & $\begin{array}{l}8 \\
9\end{array}$ & $\frac{3}{-}$ & $\overline{-}$ & - & 三 & $\begin{array}{l}14 \\
13\end{array}$ \\
\hline 2 (U.C.H.) \{ & $\begin{array}{l}4 \mathrm{~A} \\
14\end{array}$ & 3 & $\begin{array}{l}3 \\
1\end{array}$ & 11 & $\frac{1}{2}$ & $\overline{-}$ & $\overline{-}$ & $=$ & $\begin{array}{l}14 \\
14\end{array}$ \\
\hline $\begin{array}{l}3 \text { (Becken- } \\
\text { ham) } \\
4 \text { (Guy's) }\end{array}$ & $\begin{array}{l}14 \\
16 \\
20\end{array}$ & $\frac{1}{6}$ & $\begin{array}{l}\overline{2} \\
8\end{array}$ & $\begin{array}{r}2 \\
1 \\
10\end{array}$ & $\frac{1}{4}$ & $\overline{4}$ & $\begin{array}{l}2 \\
1 \\
3\end{array}$ & $\begin{array}{r}1 \\
2 \\
19\end{array}$ & $\begin{array}{r}7 \\
6 \\
54\end{array}$ \\
\hline
\end{tabular}

Study II. Comparison of Vaccine $4 A$ and Vaccine 14, Using $0.004 \mathrm{ml}$. of Gamma-globulin per lb. $(0.0088 \mathrm{ml} . / \mathrm{kg}$.) Body Weight With Each Vaccine

A study was made at University College Hospital Infant Welfare Clinic to test the effect of a smaller dose of gamma-

* Paediatric Research Unit, Guy's Hospital, London.

+ Hospital for Sick Children, Great Ormond Street, London

¥ Wellcome Research Laboratories, Beckenham, Kent.

Wellcome Foundation, Euston Road, London.

il Tuberculosis Research Unit, Medical Research Council, London. 
TABle II.-Highest Rectal Temperature, Rash, and Malaise Among Participants in Each of the Four Studies (According to the Vaccine Given)

\begin{tabular}{|c|c|c|c|c|c|c|c|c|c|c|c|c|c|}
\hline \multirow{2}{*}{ Study } & \multirow{2}{*}{ Vaccine } & \multirow{2}{*}{$\begin{array}{l}\text { Dose of } \\
\text { Gamma- } \\
\text { Globulin }\end{array}$} & \multirow{2}{*}{$\begin{array}{l}\text { Total } \\
\text { in } \\
\text { Study }\end{array}$} & \multicolumn{8}{|c|}{ Peak Temperatures in Degrees F. } & \multirow{2}{*}{ Rash } & \multirow{2}{*}{ Malaise } \\
\hline & & & & $<99$ & 99 & 100 & 101 & 102 & 103 & 104 & 105 & & \\
\hline 1 (Guy's) \{ & $\begin{array}{l}4 \mathrm{~A} \\
16 \\
\end{array}$ & $\begin{array}{l}0.02 / \text { lb. body } \\
\text { weight }\end{array}$ & $\begin{array}{l}14 \\
13 \\
\end{array}$ & $\begin{array}{l}5 \\
1 \\
\end{array}$ & $\begin{array}{l}4 \\
4 \\
\end{array}$ & $\begin{array}{l}4 \\
6\end{array}$ & $\begin{array}{l}1 \\
1\end{array}$ & $\overline{1}$ & $\overline{-}$ & $=$ & $\overline{-}$ & $\begin{array}{l}1 \\
1\end{array}$ & $\begin{array}{l}\text { Not reported } \\
\text { see text }\end{array}$ \\
\hline 2* (U.C.H.) \{ & $4 \mathrm{~A}$ & $\begin{array}{l}0.004 / \mathrm{lb} . \text { body } \\
\text { weight }\end{array}$ & $\begin{array}{l}14 \\
14 \\
\end{array}$ & $\begin{array}{l}1 \\
2 \\
\end{array}$ & $\begin{array}{l}3 \\
1 \\
\end{array}$ & $\overline{-}$ & $\overline{1}$ & $\overline{-}$ & $\overline{-}$ & $\overline{-}$ & - & $\begin{array}{l}1 \\
4 \\
\end{array}$ & $\begin{array}{l}6 \\
8 \\
\end{array}$ \\
\hline 3 (Beckenham) \{ & $\begin{array}{l}14 \\
16 \\
\end{array}$ & Not given & $\begin{array}{l}7 \\
6 \\
\end{array}$ & 1 & $\overline{1}$ & $\overline{1}$ & $\begin{array}{l}3 \\
1 \\
\end{array}$ & $\overline{2}$ & 2 & $\overline{1}$ & 1 & $\begin{array}{l}1 \\
1\end{array}$ & $\begin{array}{l}4 \\
4\end{array}$ \\
\hline 4 (Guy's) & 20 & Not given & 54 & - & 17 & 26 & 7 & 1 & 3 & - & - & 10 & $\begin{array}{l}\text { Not reported } \\
\text { see text }\end{array}$ \\
\hline
\end{tabular}

* Temperature not taken routinely.

TABL.E III.-Measles Antibody Titres After Vaccination*

\begin{tabular}{|c|c|c|c|c|c|c|c|c|c|c|c|}
\hline \multirow{2}{*}{ Study } & \multirow{2}{*}{ Vaccine } & \multicolumn{9}{|c|}{ Antibody Titres } & \multirow{2}{*}{$\begin{array}{c}\text { Not } \\
\text { Recorded }\end{array}$} \\
\hline & & $<4$ & 4 & 8 & 16 & 32 & 64 & 128 & 256 & 512 & \\
\hline 1 & $\begin{array}{c}4 \mathrm{~A} \\
16\end{array}$ & $\overline{1}$ & $\overline{-}$ & - & $\begin{array}{l}1 \\
1\end{array}$ & $\begin{array}{l}4 \\
2\end{array}$ & $\begin{array}{l}5 \\
6\end{array}$ & $\begin{array}{l}3 \\
3\end{array}$ & 1 & $\overline{-}$ & 二 \\
\hline 2 & $14^{4 A}$ & - & - & - & $\begin{array}{l}2 \\
1\end{array}$ & $\begin{array}{l}3 \\
2\end{array}$ & $\begin{array}{l}4 \\
6\end{array}$ & $\begin{array}{l}3 \\
3\end{array}$ & $\begin{array}{l}2 \\
2\end{array}$ & - & 二 \\
\hline $\begin{array}{l}3 \\
4\end{array}$ & $\begin{array}{l}14 \\
16 \\
20\end{array}$ & $\frac{-}{3}$ & $\overline{-}$ & $\overline{2}$ & $\frac{1}{2}$ & $\frac{1}{1}$ & $\overline{11}$ & $\begin{array}{r}3 \\
3 \\
19\end{array}$ & $\frac{1}{14}$ & $\overline{2}$ & $\begin{array}{r}1 \\
3 \\
\end{array}$ \\
\hline
\end{tabular}

- All antibody levels prior to vaccination were shown to be less than $1 / 4$.

globulin. Fourteen children were given vaccine $4 \mathrm{~A}$ and 14 vaccine 14 . At the time of vaccination each child was given gamma-globulin subcutaneously in the above dosage. The age range was 5 to 20 months for those given vaccine $4 \mathrm{~A}$, and 9 to 20 months for those given vaccine 14 (Table I). The homes of the children were visited during the second week after vaccination and a record was made of the condition of the child, the presence or absence of rash, and any constitutional upset. The mothers were asked to report to the clinic if the children were unwell during the two weeks after vaccination. Temperatures were not taken routinely.

The reactions to vaccination in both groups were slight (Table II). Eleven of the 28 infants had mild malaise and were irritable, with anorexia for two to three days. In a further three the symptoms were slightly more pronounced and were associated with diarrhoea and vomiting. Five had fleeting morbilliform rashes. The serum of all the infants contained measles antibody after vaccination (Table III).

\section{Study III. Comparison of Vaccine 14 and Vaccine 16 Without Gamma-globulin}

The 13 participants in this study were children of the scientific and technical staff of the Wellcome Research Laboratories. Seven were given vaccine 14 and six vaccine 16 . The youngest child was aged 7 months and the oldest 4 years (Table I). After vaccination the children were examined daily for 14 days and the rectal temperature was taken.

Ten of the 13 children had temperatures of $101^{\circ} \mathrm{F} .\left(38.3^{\circ} \mathrm{C}\right.$. $)$ or more, and one child had a temperature of $105^{\circ} \mathrm{F} .\left(40.6^{\circ} \mathrm{C}\right.$.) (Table II). Morbilliform rashes were observed in two children. Five children had malaise amounting to irritability and anorexia for two to five days, in two the malaise was pronounced, and one child had a marked constitutional upset for several days, with an aural discharge for which a course of tetracycline was given.

Measles antibody was present in all recorded serum samples after vaccination (Table III).

\section{Study IV. Vaccine 20 Without Gamma-globulin}

While these studies were proceeding vaccine 20 given without gamma-globulin had undergone field trials in Nigeria (Hendrickse et al., 1964). The result had indicated that the reactions after vaccine 20 were much less severe than those after vaccine 14 or 16. It was therefore decided to study the effect of vaccine 20 without gamma-globulin at Guy's Hospital. Fifty-four children aged from 5 months to more than 2 years (Table I) took part in the study, and daily examinations, including rectal temperatures, were made between the 6 th and the 10th day after vaccination.

The highest temperatures recorded are shown in Table II. The great majority had temperatures of $100^{\circ} \mathrm{F}$. $\left(37.8^{\circ} \mathrm{C}\right.$.) or less, and seven had temperatures of 101-101.9 $\mathrm{F}$. (38.3$38.8^{\circ} \mathrm{C}$.). Of the remaining four, one was $102-102.9^{\circ} \mathrm{F}$. (38.9$39.4^{\circ}$ C.), and three were $103-103.9^{\circ}$ F. $\left(39.4-39.9^{\circ}\right.$ C.). A total of 10 children had fleeting morbilliform rashes. Constitutional upset was slight in all cases. After vaccination the serum of all but two contained measurable measles-virus-neutralizing antibody (Table III).

The levels of antibody after vaccine 20 showed a considerable degree of scatter which to some extent was determined by the age of the vaccinated child. This finding will be commented on elsewhere (G. J. Knight, to be published). The mean antibody response to vaccine 20 was higher than that following the less-attenuated vaccines given with gammaglobulin, although lower than after such vaccines without gamma-globulin.

\section{Discussion}

A measles vaccine for routine use in the United Kingdom should provide effective protection without producing the constitutional upset, rash, and pyrexia observed after vaccination with the earlier Edmonston strains such as Beckenham 4A or 3C (Aldous et al., 1961). The effectiveness of vaccination in our trials was judged by the increase in measles antibody which has been shown to be associated with resistance to natural measles infection. The duration of this protection is as yet unknown, but has already been shown after live vaccine to be at least six years (Katz, 1964). The current report describes the progress made towards the development of a safe and effective method of immunization against measles. One such method is to modify the expected reactions by the concurrent administration of gammaglobulin; another is to use vaccines further attenuated by numerous repeated passages in chick-embryo cells. The clinical evaluation is described of three new vaccines which had undergone repeated passages. Two were given both with and without gamma-globulin; the third, which had undergone the most passages, was given alone.

When either of the new vaccines 14 and 16 were given to infants concurrently with gamma-globulin the vaccination reactions were mild. Gamma-globulin did not appear to inhibit seriously the antibody response, which was satisfactory with all the vaccines. The findings confirm the previous experience in the U.S.A. (Kress et al., 1961 ; Krugman et al., 1962 ; Stokes et al., 1962), and indicate that measles vaccine given concurrently with gamma-globulin is a safe and successful method of immunization. 
While the concurrent administration of gamma-globulin and measles vaccine would be suitable for immunization on a limited scale in England, this method would be less suitable for extensive use than an effective vaccine which produced a low reaction rate when given alone. However, a dose as small as $0.004 \mathrm{ml} . / \mathrm{lb}$. $(0.0088 \mathrm{ml} . / \mathrm{kg}$.) proved effective in one of our trials. The difficulty and expense of providing it might be counteracted by a reduction of subsequent calls on gammaglobulin as a prophylactic to susceptible contacts. Neither vaccine 14 nor vaccine 16 was found to be suitable when given without gamma-globulin. Both produced pronounced reactions when given alone, and in this respect resembled vaccine $4 \mathrm{~A}$, which had been used alone in a previous trial (Aldous et al., 1961).

In contrast to the experience with vaccines 14 and 16 , vaccine 20 produced only very mild reactions. These findings in English children confirm the more extensive observations at Ibadan University, Nigeria (Hendrickse et al., 1964).

The reason for the lower reaction rate of vaccine 20 is not quite clear. Two other vaccine strains have also been reported with low reaction rates (W.H.O., 1963). All have been passaged a large number of times in chick-embryo-tissue cultures. On the other hand, vaccine 14 was still causing marked reactions after 65 further passages in tissue culture beyond Enders's vaccine A.

The low reaction rate and satisfactory antibody response after vaccine 20 suggest that this or other vaccines attenuated to a similar degree would be suitable for use in Britain on an extensive scale.

\section{Summary}

The vaccination reaction and antibody response to Edmonston $B$ and three further attenuated measles vaccines derived from Enders's strains have been examined in a total of 122 English infants.

Enders's original vaccine alone or with further attenuation by 20 or 24 extra passages in chick-embryo tissue produced reactions which were modified by gamma-globulin in as small a dosage as $0.004 \mathrm{ml} . / \mathrm{lb}$. ( $0.0088 \mathrm{ml} . / \mathrm{kg}$.) body weight.

Vaccine 20, a further-attenuated vaccine given without gamma-globulin, caused only mild reactions but a satisfactory antibody response. Of the vaccines so far tested it appears to hold most promise of proving acceptable for routine use.

We thank Dr. R. C. Mac Keith, Miss M. Theisen, and the staff of Salomons' Centre, Guy's Hospital ; and Dr. R. E. BonhamCarter, Sister Curtis, and the staff of the Child Welfare Department, University College Hospital.

\section{REFERENCES}

Aldous, I. R., Kirman, B. H., Butler, N., Goffe, A. P., Laurence, G. D. and Pollock, T. M. (1961). Bril. med. f., 2, 1250.

Enders, J. F., Katz, S. L., Milovanović, M. V., and Holloway, A. (1960). New Engl. F. Med., 263, 153.

Goffe, A. P., and Laurence, G. D. (1961). Brit. med. 7., 2, 1244.

Hendrickse, R. G., Montefiore, D., Sherman, P. M., and van der Wall, H. M. (1964). Ibid., 1, 470.

Katz, S. L. (1964). Seminar on Epidemiology and Prevention of Measles and Rubella, International Children's Centre, Paris.

Kress, S., Schluederberg, A. E., Hornick, R. B., Morse, L. J., Cole, J. L., Slater, E. A., and McCrumb, F. R. (1961). Amer. f.' Dis. Child., 101, 701 .

Krugman, S., Giles, J. P., Jacobs, A. M., and Friedman, H. (1962) Amer. F. publ. Hith, 52, Suppl. p. 16.

Miller, D. L. (1964). Brit. med. f., 2, 75.

Stokes, J., Hilleman, M. R., Weibel, R. E., Buynak, E. B., and Halenda, R. (1962). New Engl.' \%. Med., 267, 222.

W.H.O. Scientific Group (1963). Wld Hlth Org. techn. Rep. Ser. No. 263. as suffering from poliomyelitis. Within the next four weeks numerous other patients were admitted to hospital for investigation, and of these 31 were accepted as suffering from poliomyelitis. The weekly incidence of new cases by dates of sickening is shown in Table I. Virological investigation showed that the outbreak was due to poliovirus type 1.

TABLE I.-Weekly Incidence of New Cases of Poliomyelitis by Dates \begin{tabular}{l|c|c|c|c|c|c|c}
\hline Week ending: & May 26 26 & June 2 & June 9 & June 16 & June 23 & June 30 & July 7 \\
No. of cases: & 4 & 7 & 7 & 6 & 2 & 2
\end{tabular}

Early in the outbreak it became apparent that the main incidence was in one peripheral housing scheme in the northeast of the city. Of the 40 cases finally accepted 29 came from this scheme or its immediate vicinity, while many of the others either had direct contact with this area or indirect contact through visiting relatives. Twenty cases actually occurred in close proximity to each other, and seven of these patients 